\title{
Erectile dysfunction after surgery for rectal cancer: a prospective study
}

\author{
Aylin Hande Gökçe ${ }^{1}$ (ID), Hakan Özkan²(iD) \\ ${ }^{1}$ Clinic of General Surgery, Istanbul Medicine Hospital, Istanbul, Turkey \\ ${ }^{2}$ Clinic of General Surgery, Star Medica Hospital, Tekirdag, Turkey
}

\section{ABSTRACT}

Objective: Erectile dysfunction may occur as a complication of surgical treatment of rectal cancer in male patients. We compared the rates of postoperative erectile dysfunction and response to medical treatment after low anterior resection (LAR) and Miles' procedures.

Material and Methods: Fifty patients who underwent the Miles' procedure or LAR were prospectively assessed. This study includes fifty patients with stages 1 and stage 2 rectal cancer based on clinical and radiologic assessments, who underwent Miles' (25 out of 50 patients underwent the Miles'procedure and ) or LAR (25 patients underwent LAR) procedures were prospectively assessed. The International Index of Erectile Function (IIEF) form was, used in the assessment to assess erectile dysfunction. This questionnaire, was administered preoperatively and 6 months postoperatively. For the patients with IIEF scores $\leq 25$ at postoperative $6^{\text {th }}$ months, tadalafil $5 \mathrm{mg}$ is was given for 12 weeks and IIEF is was repeated after then.

Results: No significant differences were found in mean IIEF scores preoperatively $(p=0.695)$. In both groups, IIEF scores were significantly lower postoperatively compared with preoperatively ( $p=0.00001$, LAR; $p=0.00001$, Miles'). Mean postoperative IIEF scores were significantly lower in patients who underwent Miles' compared with the LAR procedures $(p=0.0001)$. For patients with IIEF scores $\leq 25$ at 6 months, tadalafil 5 mg was given for 12 weeks and IIEF scores were better in both groups $(p=0.00001)$.

Conclusion: The erectile dysfunction rate after Miles' procedure was significantly higher than the rate of patients who developed erectile dysfunction after LAR surgery. We tried to emphasize that in after LAR surgery. We should not be concerned only with cancer treatment surgically in rectal tumour patients, but remember that situations affecting their social life, such as postoperative erectile dysfunction, have medical and psychologic importance.

Keywords: Erectile dysfunction, rectal cancer, rectal tumors, colorectal surgery

Cite this article as: Gökçe AH, Özkan H. Erectile dysfunction after surgery for rectal cancer: A prospective study. Turk J Surg 2019; 35 (4): 293-298.

Corresponding Author Aylin Hande Gökçe

E-mail: ahgokce79@hotmail.com

Received: 12.12 .2018

Accepted: 27.03.2019

Available Online Date: 28.03.2019

o Copyright 2019 by Turkish Surgical Society. Available online at www.turkjsurg.com

DOI: $10.5578 /$ turkjsurg.4397

\section{INTRODUCTION}

Rectal cancer surgery was performed by William Ernest Miles in 1908, who described abdominoperineal resection for the first time, called Miles' procedure. In the 1950s, sphincter-sparing procedures (low anterior resection [LAR]) came to the forefront. The main goals in rectal cancer surgery include low recurrence rates along with autonomic nerve preservation.

In 1970, Tsuchiya and Ohki first described autonomic nerve-sparing surgery that reduces urogenital complications, which were reported to occur in 39\% to 76\% of cases of rectal cancer surgery (1). Currently, total mesolectal excision (TME) is the standard of care for rectal cancer surgery. This procedure also aims at preserving sphincter function, if appropriate. In the TME procedure, the parietal layer of the endopelvic fascia should be spared, if possible. Special consideration should be given to the superior hypogastric and parasympathetic nerves (pelvic splanchnic nerves, pelvic plexus and its branches) lying beneath the parietal layer. Any damage to these nerves may have a central role in the development of erectile dysfunction (2). Erectile dysfunction also depends on psychologic factors, such as alcohol use, hormonal pathologies, low testosterone levels, ageing and especially chronic diseases, such as diabetes. Erectile dysfunction may occur in patients with diabetes mellitus due to vascular and neural damage $(3,4)$.

Erectile dysfunction following rectal cancer surgery is not uncommon. However, studies are limited on the development of erectile dysfunction following rectal can- 
cer surgery. Several studies have compared open, laparoscopic, transanal and robotic surgery in terms of erectile dysfunction. Erectile dysfunction has been reported by all of these studies, although at varying rates.

We determined the rates of postoperative erectile dysfunction in patients undergoing LAR and Miles' procedures for treatment of rectal cancer. We compared these procedures in terms of their impact on erectile function and investigated potential benefits of medical treatment in this patient population.

\section{MATERIAL and METHODS}

\section{Patients}

Ethics approval for this study was obtained from the ethics committee (KAEK-50-1345). Patients diagnosed with low rectal cancer (in the region between 0 and $6 \mathrm{~cm}$ from the anal verge) at our clinic were prospectively included. Patient age, comorbidities (diabetes mellitus and hypertension) and smoking status were recorded at baseline. All patients underwent colonoscopy, and rectal cancer was histologically diagnosed in obtained biopsy specimens. Screening for metastasis included chest computed tomography (CT) and whole abdomen $\mathrm{CT}$ scans and/or magnetic resonance imaging scans. On the basis of clinical and radiologic assessments, patients with stage 1 or 2 disease were included in the study, while they should be American Society of Anesthesiologists (ASA) Class 1 or 2, based on the anaesthesiology assessment. Tumour stages were determined according to the Union for International Cancer Control classifications. Study subjects received detailed information about the study, and informed written consent was provided.

Exclusion criteria included unwillingness to participate in the study, prior pelvic or urologic surgery, ASA 3 and 4 class patients, homosexual tendencies, polyposis or synchronous tumour in a different part of the large intestine detected on preoperative studies, radiologic or clinical stage 3 or 4 cancer, metastatic disease detected during surgery, non-R0 resections or major complications postoperatively.

Study subjects underwent either Miles' or LAR procedure. All surgical procedures were performed via open techniques. Frozen section tissue was examined in all patients in the LAR group and if the tissue was positive for tumour or surgical margins were inadequate, then resection was repeated, if appropriate. If re-resection was not appropriate, Miles' procedure was performed. All procedures were performed by the same surgical team.

The International Index of Erectile Function (IIEF) form was used to assess erectile dysfunction in all patients preoperatively and 6 months postoperatively. This form contained six questions evaluating erectile dysfunction by scores of 0-10 (severe), 11-16 (moderate), 17-21 (mild-to-moderate), 22-25 (mild) and 26-30 (no erectile dysfunction). For patients with an IIEF score $\leq 25$ after 6 months postoperatively, tadalafil $5 \mathrm{mg}$ was begun daily for 12 weeks and then IIEF was repeated and erectile function was re-evaluated.

\section{Statistical Analysis}

Statistical analyses were performed with Statistical Package for the Social Sciences software (Version 9.0; SPSS, Inc., Chicago, IL, USA). In addition to descriptive statistics (mean and standard deviation), the paired t-test was used in the repeated measures analysis of the groups, the independent t-test was used in twogroup comparisons and the $x^{2}$ test was used to compare qualitative data. $p<0.05$ was considered significant.

\section{RESULTS}

A total of 97 patients had low rectal cancer based on physical examination and colonoscopy. Histologic examination demonstrated adenocarcinoma in every patient. Of the 97 patients, 47 were excluded because they did not fulfil the study criteria. Mean age was $51.80 \pm 7.50$ years in the LAR group and $50.56 \pm 8.92$ years in Miles' procedure group (not statistically significant; $p=0.614$ ). No statistically significant differences were found in the rates of patients with diabetes mellitus, hypertension or smoking status $(p=0.420, p=0.275, p=0.915$, respectively; Table 1).

Mean preoperative IIEF score was $28.32 \pm 1.60$ and $28.48 \pm 1.36$ in the LAR and Miles' procedure groups, respectively (not statistically significant; $p=0.695)$. The 6 month postoperative scores were $18.92 \pm 2.79$ and $8.84 \pm 1.93$, respectively. When comparing mean preoperative and postoperative IIEF scores, the postoperative scores were significantly lower $(p=0.00001$, LAR group;

Table 1. The mean age, the prevalences of diabetes mellitus and hypertension and smoking status in study groups

\begin{tabular}{|l|c|c|c|}
\hline & $\begin{array}{c}\text { The LAR group } \\
(\mathbf{n = 2 5 )}\end{array}$ & $\begin{array}{c}\text { The Miles group } \\
(\mathbf{n = 2 5 )}\end{array}$ & $\mathrm{t}=0.511 ; p=0.614$ \\
\hline Age & $51.80 \pm 7.50$ & $50.56 \pm 8.92$ & $x^{2}=0.649 ; p=0.420$ \\
\hline DM & $3(12 \%)$ & $4(16 \%)$ & $x^{2}=1.190 ; p=0.275$ \\
\hline HT & $5(20 \%)$ & $4(16 \%)$ & $x^{2}=0.011 ; p=0.915$ \\
\hline Smoking status & $8(32 \%)$ & $9(36 \%)$ & \\
\hline \multicolumn{2}{|l}{ LAR: Low anterior resection; DM: Diabetes mellitus; HT: Hypertension. }
\end{tabular}


Table 2. Intergroup comparisons of preoperative and postoperative IIEF scores

\begin{tabular}{|l|c|c|c|c|}
\hline IIEF & $\begin{array}{c}\text { The LAR group } \\
(\mathbf{n = 2 5 )}\end{array}$ & $\begin{array}{c}\text { The Miles group } \\
(\mathbf{n = 2 5 )}\end{array}$ & $\mathbf{t}$ & $\mathbf{p}$ \\
\hline Before the surgery & $28.32 \pm 1.60$ & $28.48 \pm 1.36$ & -0.397 & 0.695 \\
\hline After the surgery & $18.92 \pm 2.79$ & $8.84 \pm 1.93$ & 18.727 & $\mathbf{0 . 0 0 0 0 1}$ \\
\hline After medical treatment & $24.92 \pm 1.75$ & $15.20 \pm 2.44$ & 15.335 & $\mathbf{0 . 0 0 0 0 1}$ \\
\hline $\mathrm{t}$ & 46.96 & 17.91 & & \\
\hline $\mathrm{P}$ & 0.00001 & 0.00001 & & \\
\hline IIEF: International Index of Erectile Function.
\end{tabular}

Table 3. Intergroup comparisons of reductions IIEF scores

\begin{tabular}{|c|c|c|c|c|}
\hline & $\begin{array}{l}\text { The LAR group } \\
\qquad(n=25)\end{array}$ & $\begin{array}{l}\text { The Miles group } \\
\qquad(n=25)\end{array}$ & $\mathbf{t}$ & $p$ \\
\hline $\begin{array}{l}\text { Reduction in IIEF scores -comparison between preoperative } \\
\text { and postoperative scores }\end{array}$ & $9.40 \pm 2.86$ & $19.64 \pm 2.04$ & -22.122 & 0.0001 \\
\hline Change \% & $33.12 \pm 9.65$ & $68.97 \pm 6.57$ & -21.718 & 0.0001 \\
\hline $\begin{array}{l}\text { Increases in IIEF scores-comparisons betwen postoperative } \\
\text { scores and scores after medical treatment }\end{array}$ & $6 \pm 2.97$ & $6.36 \pm 3.44$ & 0.423 & 0.676 \\
\hline Change \% & $34.31 \pm 20.61$ & $81.34 \pm 54.76$ & 4.332 & 0.0001 \\
\hline $\begin{array}{l}\text { Reduction in IIEF scores-comparisons between preoperative } \\
\text { scores and scores after medical medical treatment }\end{array}$ & $3.40 \pm 2.25$ & $13.28 \pm 2.73$ & -12.213 & 0.0001 \\
\hline Change \% & $11.76 \pm 7.68$ & $46.53 \pm 8.77$ & -12.993 & 0.0001 \\
\hline
\end{tabular}

$p=0.00001$ Miles' procedure group). At 6 months postoperatively, all of our patients received $5 \mathrm{mg}$ tadalafil because of IIEF scores $<25$. After 12 months of medical treatment, IIEF scores were $24.92 \pm 1.75$ in the LAR group and $15.20 \pm 2.44$ in Miles' procedure group. After medical treatment, mean preoperative IIEF scores were significantly higher than postoperative scores ( $p=0.00001$, LAR group; $p=0.00001$ Miles' procedure group; Table 2).

The decrease in mean IIEF scores was statistically significantly higher in Miles' procedure group than in the LAR group $(p=0.0001)$. The percentage reduction in mean IIEF scores was $68.97 \% \pm 6.57 \%$ in Miles' procedure group and $33.12 \pm 9.65 \%$ in the LAR group (statistically significant, $p=0.0001$ ) and the reduction in Miles' procedure group was far more remarkable. The comparison between the mean scores postoperatively and after medical treatment indicated significant improvements in both groups, which were reflected as a mean change of $6 \pm 2.97$ and $6.36 \pm 3.44$ points in the LAR and Miles' procedure groups, respectively. Intergroup comparisons did not reveal any significant difference in the rates of improvement with medical treatment. Comparisons between IIEF scores preoperatively and after medical treatment indicated significant decreases in both groups $(p=0.676, p=0.0001$; Table 3).

\section{DISCUSSION}

In rectal cancer surgery, postoperative erectile dysfunction index was reported to vary from $40 \%$ to $60 \%$ before introduction of TME. Even after introduction of nerve-sparing techniques in TME, erectile dysfunction still remains a common surgical complication with rates of $10 \%$ to $35 \%$. Several causes underlie erectile dysfunction postoperatively for rectal cancer. The most common and important cause is intraoperative injury of the pelvic autonomic nerves (5-7).

Normal sexual function in men is controlled by sympathetic branches of the superior hypogastric plexus and parasympathetic branches of the pelvic splanchnic nerves. Injuries to sympathetic nerves may result in ejaculatory problems, whereas injuries to parasympathetic nerves may result in erectile dysfunction. Injuries to these nerves are common as they are located close to the mesorectum. Meticulous dissection is of paramount importance in the TME (8).

Open, transanal and laparoscopic rectal surgeries were compared in several studies on erectile dysfunction, and different rates of erectile dysfunction have been reported. The differences between our study and previous studies include the following: (1) in other studies, the mean age of study subjects was $\geq 60$ years, compared with $<60$ years in our study subjects 
( $51.80 \pm 7.50$ and $50.56 \pm 8.92$ years in the LAR and Miles' procedure groups, respectively). (2) Patients with all stages of disease were included in the previous studies. Our study was conducted in a more homogeneous patient group (stage 1 or 2 based on clinical or radiologic assessments). (3) Several other studies included ASA 3 class patients. Our study included ASA 1 and 2 class patients with less comorbidity.

In a study comparing transanal surgery to laparoscopic surgery in patients with low rectal cancer, the mean age was 62 years. Patients with advanced disease and lymph node involvement were included in that study. In the IEFF assessment performed at least 1 year after colostomy closure and the end of chemotherapy and/or radiotherapy, the mean IIEF score was 7 in the laparoscopy group and 17.5 in the transanal surgery group however, the difference was not statistically significant (8).

Another study assessed only patients who underwent open surgery. Similar to the aforementioned study, that study also included predominantly patients $>60$ years, and patients with stages 1 to 3 disease or who had received neoadjuvant chemotherapy and/or radiotherapy also were eligible. The investigators reported that age ( $>60$ years) and low rectal cancer had no negative impact on erectile function. The average IIEF domain scores were significantly decreased postoperatively. Erectile function decreased from $14.4 \pm 10.8$ to $9.14 \pm 9.9$ ( $p<0.05)$. In parallel with our study, follow-up assessment with IIEF was performed at 6 months postoperatively and revealed the negative impact of surgery on erectile function. This negative impact was more prominent particularly in those who underwent Miles' procedure (9).

In another study of patients with similar demographic characteristics, IIEF assessments were performed preoperatively and at 3,6 and 12 months postoperatively in patients who underwent open or robotic surgery for rectal cancer. In line with our results, the negative impact on erectile function was more prominent in those who underwent Miles' procedure in that study. No significant differences were found between open and robotic surgery in terms of erectile dysfunction rates. Unlike other studies, age, lymph node involvement and tumour stage had no demonstrable effect on erectile dysfunction. Tumours in the lower rectum, neoadjuvant chemotherapy and postoperative complications reportedly have a significant negative impact on erectile function (10)

Stamopoulos et al. compared open and laparoscopic rectal surgery and found no statistically significant differences in IIEF scores. The impact on IIEF scores was lower in the LAR than in Miles' procedure groups, in agreement with our study. This study concluded that the negative impact on erectile function was more significant in stages T3 and T4 tumours compared with stages $\mathrm{T} 1$ and $\mathrm{T} 2$ tumours in patients who had received neoadjuvant chemo- and/or radiation therapy preoperatively compared with those who did not and in elderly compared with younger patients (5).

No statistically significant differences were found between the patient groups in terms of commodities (diabetes mellitus and hypertension) and smoking status. A literature search did not reveal any studies specifically focused on the impact of comorbidities; however, it is well known that comorbidities and smoking have a negative impact on erectile function.

Normal sexual function is controlled by the sympathetic system. However, dysfunction may result from damage to the parasympathetic system. Superior hypogastric plexus and parasympathetic nerves (pelvic splanchnic nerves, pelvic plexus and its branches) should be preserved during TME procedures. Preservation of the pudendal nerves during dissection of the rectum may reduce the risk of erectile dysfunction. Therefore, perirectal and perineal muscles should be avoided during dissection as long as possible, as the pudendal nerves pass through these muscles. Even partial preservation of pelvic nerves was reported to maintain sexual function $(11,12)$. However, as seen in the study of Ameda and Hendren, erectile dysfunction remains a serious complication of rectal cancer surgery, even in nerve-sparing procedures (13). Dong Kil Li reported a $61 \%$ reduction in late IIEF scores following nerve-sparing surgery (14). There studies report significant improvement in postoperative erectile dysfunction following treatment with udenafil given orally (15). In a study performed by Yavascaoglu et al., Sildenafil citrate treatment, which is a citrate-selective phosphodiesterase-5 inhibitor in erectile dysfunction caused by chronic diseases, reached a treatment level of $66.6 \%$ (16). Our patients at least partially benefited from tadalafil daily $5 \mathrm{mg}$ given for erectile dysfunction.

Psychologic factors are considered to have a role in erectile dysfunction in these patients. Being aware of their cancer, feeling helpless and worrying about staying alive are important factors. In addition, psychologic impact was related to treatment with chemotherapy or radiotherapy, and the impact of colostomy/ileostomy on patients' mood further contributed to the development of erectile dysfunction. Postoperative erectile dysfunction should be assessed by urologists in collaboration with psychiatrists to bring these patients back to their usual life. Gradual decrease in the age at occurrence of rectal cancer further emphasises the importance of the resolution of this complication.

The number of patients in our study was limited. In addition, we cannot say that we do not evaluate psychologic (depression and anxiety) parameters, which may be effective on erectile dysfunction in patients with cancer who have had major surgery.

\section{CONCLUSION}

Regardless of the surgical technique used for rectal cancer, erectile dysfunction may occur as a serious, prevalent complication. This complication is more common in patients who undergo 
Miles' procedure. We believe that, in addition to adequate preoperative psychologic support, careful surgical dissection and postoperative psychologic support when required, urologic support also is necessary in these patients.

\section{ACKNOWLEDGEMENT}

I would like to thank to MD Associate professor Dr. Acar Aren for his kind acknowledgements to our paper.

Ethics Committee Approval: Authors declared that the research was conducted in accordance with the principles of the World Medical Association Declaration of Helsinki "Ethical Principles for Medical Research Involving Human Subjects". Ethics approval for this study was obtained from the Ethics Committee (KAEK-50-1345).

Informed Consent: Written informed consent was obtained from patients who participated in this study.

Peer-review: Externally peer-reviewed.

Author Contributions: Consept - A.H.G., H.Ö.; Design - A.H.G., H.Ö.; Supervision - A.H.G., H.Ö.; Resource - A.H.G., H.Ö.; Materials - A.H.G., H.Ö.; Data Collection and/or Processing - A.H.G., H.Ö.; Analysis and Interpretation - A.H.G., H.Ö.; Literature Search - A.H.G., H.Ö.; Writing Manuscript - A.H.G., H.Ö.; Critical Reviews - A.H.G., H.Ö.

Conflict of Interest: The authors have no conflicts of interest to declare.

Financial Disclosure: The authors declared that this study has received no financial support.

\section{REFERENCES}

1. Engel J, Kerr J, Schlessinger-Raab A, Eckel R, Sauer H, Hölzel D. Quality of life in rectal cancer patients: a four-year prospective study. Ann Surg 2003;238:203-13. [CrossRef]

2. Keating J. Sexual function after rectal excision. ANZJ Surg 2004;74:24859. [CrossRef]

3. Vatansever BT, Tekin S, Karabayraktar T, Çınkıt B, Temizkan Ş, Orbay E, et al. Evaluation of risk factors for erectile dysfunction in diabetic men. Ankara Med J 2015;15:59-66. [CrossRef]

4. Sarier M, Soylu A, Baydinç YC. Necessity of endocrine screening in men with erectile dysfunction. SDÜ Tıp Fakültesi Dergisi 2018:25:356-60. [CrossRef]
5. Stamopoulos P, Theodoropoulos GE, Papailiou J, Savidis D, Golemati C, Bramis K, et al. Prospective evaluation of sexual function after open and laparoscopic surgery for rectal cancer. Surg Endosc 2009;23:2665-74. [CrossRef]

6. Huang M, Lin J, Yu X, Chen S, Kang L, Deng Y, et al. Erectile and urinary function in men with rectal cancer treated by neoadjuvant chemoradiotherapy and neoadjuvant chemotherapy alone. A randomized trial report. Int J Colorectal Dis 2016;31:1349-57. [CrossRef]

7. Saito S, Fujita S, Mizusawa J, Kanemitsu Y, Saito N, Kinugasa Y, et al. Male sexual dysfunction after rectal cancer surgery: Results of a randomized trial comparing mesorectal excision with and without lateral lymph node dissection for patients with lower rectal cancer. Eur $J$ Surg Oncol 2016:42:1851-58.[CrossRef]

8. Pontallier A, Denost Q, Geluwe BW, Adam JP, Celerier B, Rullier E. Potential sexual function improvement by using transanal mesorectal approach for laparoscopic low rectal cancer excision. Surg Endosc 2016;30:4924-33.[CrossRef]

9. Dulskas A, Samalavicius NEA. A prospective study of sexual and urinary function before and after total mesorectal excision. Int J Colorectal Dis 2016;31:1125-30.[CrossRef]

10. Ozeki S, Maeda K, Hanai T, Masumori K, Katsuno H, Takahashi $\mathrm{H}$. Effects of robotic rectal surgery on sexual and urinary functions in male patients. Surg Today 2016;46:491-500. [CrossRef]

11. Celentano V, Cohen R, Warusavitarne J, Faiz O, Chand M. Sexual dysfunction following rectal cancer surgery. Int J Colorectal Dis 2017;32:1523-30. [CrossRef]

12. Hendren SK, O'Connor BI, Liu M, Asano T, Cohen Z, Swallow CJ, et al. Prevalence of male and female sexual dysfunction is high following surgery for rectal cancer. Ann Surg 2005;242:212-23. [CrossRef]

13. Ameda K, Kakizaki H, Koyanagi T, Hirakawa K, Kusumi T, Hosokawa M. The long-term voiding function and sexual function after pelvic nerve-sparing radical surgery for rectal cancer. Int J Urol 2005;12:25663. [CrossRef]

14. Lee DK, Jo MK, Song K, Park JW, Moon SM. Voiding and sexual function after autonomic-nerve-preserving surgery for rectal cancer in disease-free male patients. Korean J Urol 2010;51:858-62. [CrossRef]

15. Park SY, Choi GS, Park JS, Kim HJ, Park JA, Choi JI. Efficacy and safety of udenafil for the treatment of erectile dysfunction after total mesorectal excision of rectal cancer: a randomized, double-blind, placebo-controlled trial. Surgery 2015;157:64-71.[CrossRef]

16. Yavascaoglu I, Vuruskan H, Oktay B. Efficacy and safety of sildenafil citrate in patients with erectile dysfunction. Uludağ Üniversitesi Tıp Fakültesi Dergisi 2003;29:15-8. 


\title{
ORIJINAL ÇALIŞMA-ÖZET
}

Turk J Surg 2019; 35 (4): 293-298

\section{Rektum kanser cerrahisi sonrası erektil disfonksiyon; prospektif bir çalışma}

\author{
Aylin Hande Gökçe ${ }^{1}$, Hakan Özkan ${ }^{2}$ \\ 1 İstanbul Medicine Hastanesi, Genel Cerrahi Kliniği, İstanbul, Türkiye \\ ${ }^{2}$ Star Medica Hastanesi, Genel Cerrahi Kliniği, Tekirdağ, Türkiye
}

\section{ÖZET}

Giriş ve Amaç: Rektum kanseri cerrahi tedavisi sonrası erkek hastalarda erektil disfonksiyon görülebilen bir komplikasyondur. Bu çalışmada amacımız rektum kanseri sebebiyle low anterior rezeksiyon (LAR) veya Miles prosedürü uygulanan hastaların postoperatif erektil disfonksiyon gelişim oranını ve medikal tedaviye cevabı karşılaştırmaktır.

Gereç ve Yöntem: Kliniğimizde rektum kanseri nedeniyle Miles prosedürü veya LAR uygulanan 50 hasta prospektif olarak değerlendirildi. Çalışmaya klinik ve radyolojik olarak evre 1 ve 2 kategorisinde olan hastalar alındı. Yirmi beş hastaya Miles prosedürü 25 hastaya ise LAR ameliyatı uygulandı. Postoperatif erektil disfonksiyon değerlendirilmesinde, ereksiyon işlevi uluslararası değerlendirme formu (IIEF) kullanıldı. Bu form ameliyat öncesi ve postoperatif altıncı ayda uygulandı. Postoperatif altıncı ayda yapılan IIEF formunda $25^{\prime}$ in altı değeri olan olgulara her gün $5 \mathrm{mg}$ tadalafil tedavisine başlandı ve 12 hafta sonra tekrar IIEF formu uygulandı ve medikal tedavi cevabı değerlendirildi.

Bulgular: LAR ve Miles gruplarının ameliyat öncesi IIEF ortalamaları arasında istatistiksel farklılık yoktu $(p=0.695)$. Her iki grupta ameliyat sonrası IIEF düzeyi ameliyat öncesine göre belirgin düşük olarak saptandı (LAR grubu $p=0.00001$, Miles grubu $p=0.00001$ ). Miles ameliyatı olan hastaların ameliyat sonrası IIEF ortalamaları, LAR ameliyatı olan hastalardan istatistiksel olarak anlamlı derecede düşük bulundu ( $p=0.0001)$. Postoperatif altıncı ay sonunda IIEF skoru 25 altı olan olguların 12 hafta günlük tadalafil kullanımı sonrası her iki grupta da IIEF skorlamasında yükselme saptandı $(p=0.00001)$.

Sonuç: Miles prosedürü uygulanan hastalarda postoperatif gelişen erektil disfonksiyon oranı LAR yapılan hastalardan daha yüksektir. Rektum kanseri olan olgularda sadece kansere yönelik cerrahi veya medikal tedaviyle ilgilenmememiz, postoperatif erektil disfonksiyon gibi sosyal yaşamlarını etkileyen durumları hatırlamamız gerektiğini ve bu durumlarlada medikal, psikolojik desteği sağlamamız gerektiğini vurgulamak istedik.

Anahtar Kelimeler: Erektil disfonksiyon, rektum kanseri, rektal tümörler, kolorektal cerrahi

Doi: $10.5578 /$ turkjsurg.4397 